\title{
Effect of aquaculture on world fish supplies
}

\author{
Rosamond L. Naylor ${ }^{\star}$ Rebecca J. Goldburg $\dagger$, Jurgenne H. Primavera $\ddagger$, Nils Kautsky $§ \|$, Malcolm C. M. Beveridgeg, Jason Clay\#, \\ Carl Folke $\$ \|$, Jane Lubchenco ${ }^{\star}$, Harold Mooney ${ }^{\star}$ \& Max Troell $\S \|$
}

* Stanford University, Institute for International Studies, Encina Hall 400E, Stanford University, Stanford, California 94305-6055, USA

$\dagger$ Environmental Defense, 257 Park Avenue South, New York, New York 10010, USA

$\ddagger$ Aquaculture Department, Southeast Asian Fisheries Development Center, Tigbauan, Iloilo, 5021, Philippines

$\$$ Department of Systems Ecology, Stockholm University, S-106 91 Stockholm, Sweden

\| The Beijer Institute, Stockholm, Sweden

Institute of Aquaculture, University of Stirling, Stirling FK9 4LA, UK

\# World Wildlife Fund, 1250 24th Street NW, Washington DC 20037, USA

Department of Zoology, Oregon State University, Corvalles, Oregon 97331-2914, USA

Global production of farmed fish and shellfish has more than doubled in the past 15 years. Many people believe that such growth relieves pressure on ocean fisheries, but the opposite is true for some types of aquaculture. Farming carnivorous species requires large inputs of wild fish for feed. Some aquaculture systems also reduce wild fish supplies through habitat modification, wild seedstock collection and other ecological impacts. On balance, global aquaculture production still adds to world fish supplies; however, if the growing aquaculture industry is to sustain its contribution to world fish supplies, it must reduce wild fish inputs in feed and adopt more ecologically sound management practices.

The worldwide decline of ocean fisheries stocks has provided impetus for rapid growth in fish and shellfish farming, or aquaculture. Between 1987 and 1997, global production of farmed fish and shellfish (collectively called 'fish') more than doubled in weight and value, as did its contribution to world fish supplies ${ }^{1}$. Fish produced from farming activities currently accounts for over onequarter of all fish directly consumed by humans. As the human population continues to expand beyond 6 billion, its reliance on farmed fish production as an important source of protein will also increase.

Growth in aquaculture production is a mixed blessing, however, for the sustainability of ocean fisheries. For some types of aquaculture activity, including shrimp and salmon farming, potential damage to ocean and coastal resources through habitat destruction, waste disposal, exotic species and pathogen invasions, and large fish meal and fish oil requirements may further deplete wild fisheries stocks ${ }^{2}$. For other aquaculture species, such as carp and molluscs, which are herbivorous or filter feeders, the net contribution to global fish supplies and food security is great ${ }^{3}$. The diversity of production systems leads to an underlying paradox: aquaculture is a possible solution, but also a contributing factor, to the collapse of fisheries stocks worldwide.

Here we examine marine and freshwater fish farming activities around the world and ask: does aquaculture enhance-or diminish-the available fish supply? This is an important scientific and policy issue, and one that also addresses the common perception that aquaculture is an 'add on' to current ocean fish productivity. Many people believe that aquaculture production will compensate for the shortfall in ocean harvests as ocean fisheries deteriorate, or that fish farming will restore wild populations by relieving pressure on capture fisheries. We conclude that the compensation argument is correct for some aquaculture practices but unfounded for others. We do not find evidence that supports the restoration argument.

Our analysis focuses on aquaculture trends in the past 10-15 years - a period of heightened ecological and economic integration between capture fisheries and aquaculture activities. We limit our discussion to finfish, bivalves and crustaceans, which collectively make up three-quarters of global aquaculture production by weight, and exclude seaweed production ${ }^{1}$. Ocean fisheries and aquaculture now share or compete for many coastal ecosystem services, including the provision of habitat and nursery areas, feed and seed (larvae) supplies, and assimilation of waste products. Aquaculture and ocean fisheries are further linked economically through competition in world markets for the sale of their products, and biologically through exotic species invasions and pathogen transmission. Each of these connections is examined below.

As aquaculture production continues to increase and intensify, both its reliance and its impact on ocean fisheries are likely to expand even further. The balance between farmed and wild-caught fish, as well as the total supply of fish available for human consumption, will depend on future aquaculture practices. In the final section, we explore technological, management and policy options for sustaining aquaculture production. We argue that farming can contribute to global (net) fish supplies only if current trends in fish meal and fish oil use for aquaculture are reversed and policies are enforced to protect coastal areas from environmental degradation.

\section{Aquaculture is a diverse activity}

More than 220 species of finfish and shellfish are farmed; the range includes giant clams, which obtain most of their nutrients from symbiotic algae; mussels, which filter plankton; carps, which are mainly herbivorous; and salmon, which are carnivorous ${ }^{1}$. Two key criteria, ownership of stock and deliberate intervention in the production cycle (husbandry), distinguish aquaculture from capture fisheries. Fish farming typically involves the enclosure of fish in a secure system under conditions in which they can thrive. Interventions in fish life cycles range from exclusion of predators and control of competitors (extensive aquaculture) to enhancement of food supply (semi-intensive) to the provision of all nutritional requirements (intensive). Intensification implies increasing the density of individuals, which requires greater use and management of inputs, greater generation of waste products and increased potential for the spread of pathogens.

Production practices and their impacts on marine ecosystems vary widely. Molluscs are generally farmed along coastlines where wild or hatchery-reared seed are grown on the seabed bottom or in suspended nets, ropes or other structures. The animals rely entirely 
on ambient supplies of plankton and organic particles for food. Several systems-ponds, tanks or cages-are used in farming finfish. Most marine and diadromous finfish are reared in floating net cages nearshore, and all their nutrition is supplied by formulated feeds. Carp and other freshwater finfish are usually grown in ponds, often integrated within agricultural ecosystems. Shrimp dominate crustacean farming and are grown in coastal ponds. Farming of both shrimp and freshwater finfish varies in its intensity and dependence on formulated feeds.

Within aquaculture's wide diversity of species and production practices, two distinct subsectors have emerged during the past decade $^{4}$. The first group includes commercial farms that primarily use intensive and semi-intensive methods to produce medium- to high-valued commodities for regional or global markets. The other group encompasses family and cooperative farms that rely on extensive and semi-intensive practices to produce low-value species for household subsistence or local markets. Some divisions between these sectors are becoming blurred. In China and other parts of Asia, for example, many small-scale farming operations are intensifying as land and water resources become increasingly scarce and valuable ${ }^{5}$.

Harvested weight and value for some of the most widely consumed aquaculture species are shown in Table 1. Asia accounts for roughly $90 \%$ of global aquaculture production, and China alone contributes more than two-thirds of the total ${ }^{1}$. Europe, North America and Japan collectively produce just over one-tenth of global aquaculture output but consume the bulk of farmed seafood that is traded internationally.

The production of carp has increased markedly in Asia (mainly China) for local or regional consumption by relatively low-income households. In contrast, increased volumes of salmon, shrimp and other high-value species have been marketed mainly in industrialized countries. Farmed output and markets for other lower-value species, such as tilapia and milkfish, have increased in both developing and industrialized countries. Most farmed molluscs are still consumed locally and regionally in China and in other developing countries. However, production for global markets of certain species, including the Pacific cupped oyster, blue mussel, New Zealand mussel and Yesso scallop, has increased in several developed countries ${ }^{1}$.

Market dynamics affecting both the supply and demand for aquaculture products differ sharply among types of fish. Expanding aquaculture production can alleviate pressure on wild fisheries stocks; for example, increasing the production of farmed fish that compete directly with wild fish (such as shrimp, salmon and molluscs) reduces prices and creates conditions that can lower investments in fishing fleets and fishing effort over time. Other farmed fish, such as tilapia, milkfish and channel catfish, provide alternatives to ocean fish such as cod, hake, haddock and pollock. Because niche markets have started to develop for several types of wild-caught fish, however, capture rates have remained high even as the production of viable substitutes has increased ${ }^{4}$.

The ability of the aquaculture sector to replace or provide market

\begin{tabular}{|c|c|c|c|}
\hline Species & $\begin{array}{l}1997 \text { weight } \\
\text { (kilotonnes) }\end{array}$ & $\begin{array}{c}\text { Annual weight growth } \\
(1987-97) \%\end{array}$ & $\begin{array}{l}1997 \text { value in } \\
\text { US\$ (millions) }\end{array}$ \\
\hline Common carp & 2,237 & 7.6 & 2,709 \\
\hline Grass carp & 2,662 & 15.9 & 2,444 \\
\hline Silver carp & 3,146 & 7.8 & 2,917 \\
\hline Nile tilapia & 742 & 18.0 & 885 \\
\hline Channel catfish & 238 & 3.4 & 372 \\
\hline Atlantic salmon & 639 & 22.4 & 2,113 \\
\hline Milkfish & 393 & 1.7 & 697 \\
\hline Giant tiger prawn & 490 & 10.6 & 3,501 \\
\hline Pacific cupped oyster* & 2,968 & 9.5 & 3,164 \\
\hline
\end{tabular}

${ }^{*}$ Weight includes shell. alternatives for ocean catches depends significantly on the economics and policies of fisheries. High fixed costs of fishing fleets, inelastic supplies of labour in the fishing industry, and continued subsidies to the fisheries sector that approach $20-25 \%$ of gross revenue globally ${ }^{6}$ may mean that increased aquaculture production will not result in lower catches of wild fish in the short term. In the case of salmon, increased farm production has not resulted in reduced capture levels despite $30-50 \%$ declines in international prices for four of the five main species of wild salmon (chinook, coho, pink and chum) during the 1990s. Salmon catches worldwide actually rose by 27\% between 1988 and 1997 (ref. 7). Similarly, despite rapid growth in alternative farmed fish like tilapia, wild capture of hake and haddock remained relatively stable during the past decade ${ }^{8}$. These examples show little obvious effect of aquaculture production on capture rates of wild fish.

\section{Fishing down and farming up the food web}

Capture fisheries landings as a whole have plateaued at around 85$95 \mathrm{Mt}$ (million metric tonnes, or megatonnes) per year ${ }^{8}$. Moreover, there has been a gradual shift in wild fish capture from large and valuable carnivorous species to smaller, less valuable species that feed at lower trophic levels ${ }^{9}$. Although catch rates for some species have not declined during the 1990s, most ocean fisheries stocks are now recognized as over or fully fished ${ }^{10}$.

Aquaculture production, meanwhile, has surged, particularly during the past $10-15$ years. Farmed fish supplies totalled $29 \mathrm{Mt}$ in 1997 , compared with $10 \mathrm{Mt}$ a decade ago ${ }^{1}$. Such growth helps to explain current patterns in ocean fish capture; between 1986 and 1997,4 of the top 5, and 8 of the top 20 capture species were used in feed production for the aquaculture and livestock industries ${ }^{8}$. These species - anchoveta, Chilean jack mackerel, Atlantic herring, chub mackerel, Japanese anchovy, round sardinella, Atlantic mackerel and European anchovy-are all small pelagic fishes.

Many intensive and semi-intensive aquaculture systems use 2-5 times more fish protein, in the form of fish meal, to feed the farmed species than is supplied by the farmed product ${ }^{11}$. In contrast, extensive and traditional systems use little or no fish meal, although nutrient-rich materials are often added to the water to stimulate growth of algae and other organisms on which the fish feed. Dietary requirements vary widely among fish species, depending on the aquaculture system, fish meal source and other dietary components (Table 2).

About $80 \%$ of carp and $65 \%$ of tilapia worldwide are farmed without the use of modern compound feeds-feeds formulated from multiple ingredients. In China, farmed production of carp and other omnivorous species is intensifying, however, and new commercial feed mills are being developed to serve these industries ${ }^{5,12}$. More modern, intensive systems for herbivorous and omnivorous finfish rely heavily on added feeds, because fish are stocked at high densities that cannot be supported by natural food sources. Such systems, for example, US catfish farms, generally use compound feeds that contain high percentages of protein supplements from soybean meal, cottonseed meal and peanut meal ${ }^{13}$. Compound feeds for herbivorous and omnivorous finfish can also contain low to moderate levels of protein from fish and terrestrial animals.

In contrast, fish meal and fish oil are dominant ingredients in compound feeds for carnivorous finfish and marine shrimp. These two ingredients supply essential amino acids (such as lysine and methionine) that are deficient in plant proteins and fatty acids (eicosapentanoic acid (EPA) and docosahexanoic acid (DHA)) not found in vegetable oils ${ }^{14}$. They also provide energy, which is important because fish tend to convert carbohydrates to energy inefficiently ${ }^{14}$.

Herbivorous, omnivorous and carnivorous finfish all require about the same quantity of dietary protein per unit weight. But herbivorous and omnivorous freshwater finfish, such as carp, utilize plant-based proteins and oils better than carnivorous finfish, and 
they require minimal quantities of fish meal to supply essential amino acids ${ }^{14}$. Nevertheless, compound feeds for omnivorous fish, such as tilapia, often contain about $15 \%$ fish meal, exceeding required levels ${ }^{11}$. Manufacturers often over-formulate feeds, in part because dietary information for particular species is insufficient.

Because of the high levels of fish meal and fish oil in aquaculture feeds, many species require more fish biomass as inputs than the farmed fish produced. For the ten types of fish most commonly farmed, an average of $1.9 \mathrm{~kg}$ of wild fish is required for every kilogram of fish raised on compound feeds (Table 2). Only three of the ten types of fish - catfish, milkfish and carp-require less fish as inputs than is ultimately harvested. (Marine molluscs and many filter-feeding carp are not fed compound feeds at all.) In contrast, carnivorous species require $2.5-5$ times as much fish biomass as feed as is produced.

Although aquaculture has the fastest growing demand for fish meal and fish oil, fish are not the only animals fed diets containing fish meal. The poultry and swine industries are the world's largest consumers of fish meal ${ }^{15}$. The proportion of fish meal in aquaculture feeds is, however, much higher than in poultry and livestock feeds, which on average contain only $2-3 \%$ fish meal as a protein supplement. The production of a kilogram of pork or poultry typically uses large amounts of plant proteins, but only a few hundred grams of fish, whereas production of a kilogram of carnivorous fish can use up to $5 \mathrm{~kg}$ of wild fish ${ }^{16}$.

The relative feed efficiency of fish farming is a complex subject that has not yet been fully analysed. Some aquaculture proponents argue that even if farmed fish production requires more wild fish biomass than is ultimately harvested, it is still more efficient than the production of commercially valuable carnivorous species in the wild ${ }^{17}$. Assuming a canonical value of a $10 \%$ energy flow between trophic levels ${ }^{18}$, producing 1 unit of predatory fish requires 10 units of food (largely small pelagic fish) compared with 2-5 units to produce a unit of farmed fish. This comparison is subject to debate, because energy flows between marine fish at different trophic levels are not well documented. Nevertheless, such efficiency comparisons bolster the logic for using some small pelagic fish in fish feeds.

Regardless of the exact efficiency ratio used, however, the growing aquaculture industry cannot continue to rely on finite stocks of wild-caught fish, a number of which are already classified as fully exploited, overexploited or depleted ${ }^{8,10}$. Taking efficiency arguments to their logical conclusion - that ever increasing amounts of small pelagic fish should be caught for use in aquaculture feeds to expand the total supply of commercially valuable fish-would clearly be disastrous for marine ecosystems. Such an approach would also severely constrain the long-term growth of the aquaculture industry itself.

\section{Appropriation of net aquatic primary production}

Data in the preceding section indicate that feed requirements for some types of aquaculture systems place a strain on wild fish stocks. But what is the aggregate impact of fish farming on ocean fisheries and marine resources? Tracing the flow of net aquatic primary production that moves through aquaculture (Fig. 1) provides a framework for assessing whether farmed fish production adds to global fish supplies on a net basis.

An estimated $8 \%$ of total aquatic primary production $(137,000$ Mt dry weight) is needed to sustain capture fisheries, seaweed collection and aquaculture; this proportion ranges from $2 \%$ in the open ocean to $24-35 \%$ in freshwater, shelf and upwelling systems ${ }^{19}$. Global capture fisheries (plus aquatic plants) remove $123 \mathrm{Mt}$ from the sea and lakes ${ }^{20}$, of which $27 \mathrm{Mt}$ is directly discarded as bycatch ${ }^{21}$.

Capture fisheries landings (excluding discarded bycatch) amount to $96 \mathrm{Mt}$, of which $65 \mathrm{Mt}$ of whole fish and $1 \mathrm{Mt}$ of seaweeds are consumed by humans. The remaining $30 \mathrm{Mt}$ of fish catch plus another $2 \mathrm{Mt}$ of processing scraps from aquaculture and fisheries are used for fish meal production ${ }^{22}$. The fish meal industry has proposed that fishing vessels be encouraged to retain bycatch, now discarded, for sale to producers of fish meal and fish oil ${ }^{15}$.Sale of bycatch could prove undesirable, however, if it undermines efforts to reduce bycatch rates or decreases in situ recycling of bycatch.

One-third of the fish used to make fish meal inputs, $\sim 10 \mathrm{Mt}$, is converted to aquaculture feeds $\mathrm{s}^{20,22}$. The remaining two-thirds of the fish, $\sim 22 \mathrm{Mt}$, is used to make fish meal for chicken, pig and other animal feeds, although the share of aquaculture continues to increase. The proportion of fish meal supplies used for farming fish rose from $10 \%$ in 1988 to $17 \%$ in 1994 and $33 \%$ in 1997 (refs 22-24).

Other feed inputs to aquaculture are derived from terrestrial agriculture or, in the case of filter-feeding molluscs, from planktonic production. Pelagic and benthic microalgae are also consumed directly by herbivorous and omnivorous carp and tilapias and are thus important in extensive and semi-intensive freshwater ponds common in the tropics. Mollusc farming and other extensive aquaculture do not use compound feeds and do not therefore appropriate fisheries production directly.

Total aquaculture production of finfish, crustaceans and molluscs amounts to $29 \mathrm{Mt}$ (plus $8 \mathrm{Mt}$ of farmed seaweeds). However, the net volume of fish flowing to human consumption through aquaculture is at maximum $19 \mathrm{Mt}$ after ocean fisheries capture for fish feeds is

Table 2 Wild fish inputs used in feed for the ten types of fish and shell fish most commonly farmed in 1997*

\begin{tabular}{|c|c|c|c|c|c|c|c|c|}
\hline Farmed fish & $\begin{array}{l}\text { Total production } \\
\text { (kilotonnes) }\end{array}$ & $\begin{array}{c}\text { Percentage } \\
\text { produced with } \\
\text { compound feeds } \\
\text { (by weight) }\end{array}$ & $\begin{array}{l}\text { Production with } \\
\text { compound feeds } \\
\text { (kilotonnes) }\end{array}$ & $\begin{array}{l}\text { Percentage fishmeal } \\
\text { in feed }\end{array}$ & $\begin{array}{l}\text { Percentage fish } \\
\text { oil in feed }\end{array}$ & $\begin{array}{l}\text { Average feed } \\
\text { conversion ratio }\end{array}$ & $\begin{array}{l}\text { Wild fish used for } \\
\text { fishmeal (kilotonnes) }\end{array}$ & $\begin{array}{l}\text { Ratio of wild fish: } \\
\text { fed farmed fish† }\end{array}$ \\
\hline Marine finfish $\ddagger$ & 754 & 50 & 377 & 50 & 15 & 2.2 & 1,944 & 5.16 \\
\hline Eel & 233 & 50 & 117 & 50 & 10 & 2 & 546 & 4.69 \\
\hline Marine Shrimp & 942 & 77 & 725 & 30 & 2 & 2 & 2,040 & 2.81 \\
\hline Salmon & 737 & 100 & 737 & 45 & 25 & 1.5 & 2,332 & 3.16 \\
\hline Trout & 473 & 100 & 473 & 35 & 20 & 1.5 & 1,164 & 2.46 \\
\hline Tilapia & 946 & 35 & 331 & 15 & 1 & 2 & 466 & 1.41 \\
\hline Milkfish & 392 & 20 & 78 & 10 & 3 & 2 & 74 & 0.94 \\
\hline Catfish & 428 & 82 & 351 & 10 & 3 & 1.8 & 296 & 0.84 \\
\hline \multicolumn{9}{|l|}{ Carp§ } \\
\hline Fed & 6,985 & 35 & 2,445 & 8 & 1 & 2 & 1,834 & 0.75 \\
\hline Filter-feeding & 5,189 & 0 & 0 & - & - & - & - & - \\
\hline Molluscs & 7,321 & 0 & 0 & - & - & - & - & - \\
\hline Total & 24,400 & & 5,634 & & & & 10,695 & 1.90 \\
\hline
\end{tabular}

* Taken from refs 1, 16, 23 and A. Tacon, personal communication.

$\dagger$ Ratio is wild fish used for fishmeal to farmed fish produced using compound feeds. We assume a 5:1 conversion ratio of fish ('wet weights') to fishmeal and that one-sixteenth of fishmeal is obtained from processing byproducts ${ }^{22}$

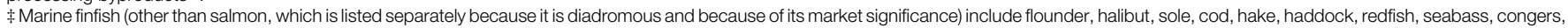
tuna, bonito and billfish.

$\S$ Fed carp refers to carp species that are sometimes fed compound feeds. Filter-feeding carp are silver carp, bighead carp and catla. 


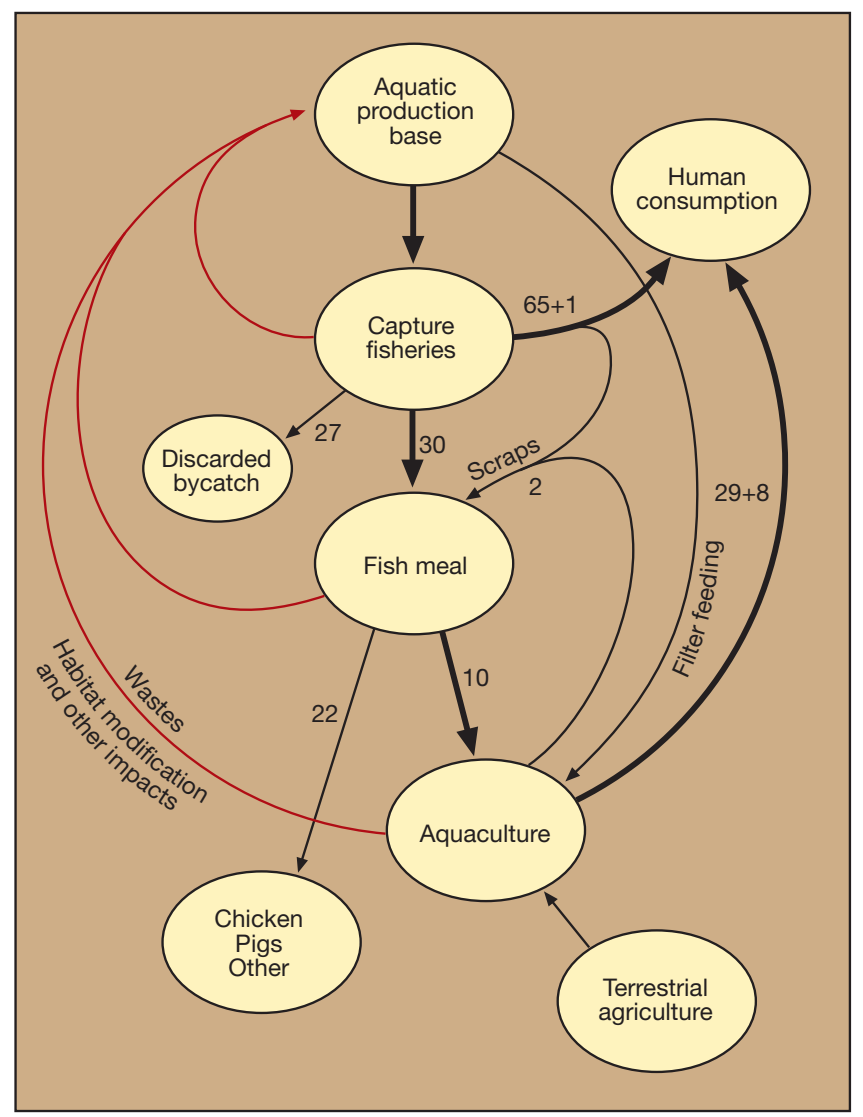

Figure 1 Flow chart of capture and farmed fisheries products from aquatic primary production. Numbers refer to 1997 data and are in units of megatons (million metric tonnes) of fish. Thicker lines refer to direct flows of aquatic primary production through capture fisheries and aquaculture to humans. Thin lines refer to indirect and minor flows. Red lines indicate negative feedbacks on production base. subtracted. The appropriation of aquatic productivity for fish feeds reduces supplies of wild fish that could potentially be consumed directly. In southeast Asia, for example, small pelagic fishes, such as mackerel, anchovy and sardines, provide an important protein source for people $\mathrm{e}^{25,26}$. Although some fish used for fishmeal and fish oil, such as menhaden, are distasteful to humans, the demand for small pelagic fish for direct human consumption is likely to increase with population growth in the developing world.

\section{Ecological links between aquaculture and wild fish stocks}

The use of wild fish to feed farmed fish places direct pressure on fisheries resources. But aquaculture can also diminish wild fisheries indirectly by habitat modification, collection of wild seedstock, food web interactions, introduction of exotic species and pathogens that harm wild fish populations, and nutrient pollution (Fig. 2). The magnitude of such effects varies considerably among aquaculture systems, but it can be great, as the following examples illustrate.

Habitat modification. Hundreds of thousands of hectares of mangroves and coastal wetlands have been transformed into milkfish and shrimp ponds. This transformation results in loss of essential ecosystem services generated by mangroves, including the provision of nursery habitat, coastal protection, flood control, sediment trapping and water treatment. Mangrove forests serve as nurseries that provide food and shelter to many juvenile finfish and shellfish caught as adults in coastal and offshore fisheries ${ }^{27-30}$; in southeast Asia, mangrove-dependent species account for roughly one-third of yearly wild fish landings excluding trash fish ${ }^{31}$. A positive relationship between finfish and shrimp landings and mangrove area has been documented in Indonesia, Malaysia and the Philippines ${ }^{32-34}$. Mangroves are also linked closely to habitat conditions of coral reefs and seagrass bed $s^{35,36}$. Loss of mangrove forests results in increased sediment transport onto downstream coral reefs. Fisheries capture from reefs contributes about $10 \%$ of human fish consumption globally and much more in developing countries $^{37}$.

The loss in wild fisheries stocks due to habitat conversion associated with shrimp farming is large. We estimate that a total of $400 \mathrm{~g}$ of fish and shrimp are lost from capture fisheries per kilogram of shrimp farmed in Thai shrimp ponds developed in mangroves (Box 1). If other fish and shellfish species caught in waterways adjoining mangrove areas are considered, the total reduction increases to $447 \mathrm{~g}$ of wild fish biomass per kilogram of shrimp raised. If the full range of ecological effects associated with mangrove conversion is accounted for, including reduced mollusc productivity in mangroves and losses to seagrass beds and coral reefs, the net yield from these shrimp farms is low-even without considering the use of fish meal in aquaculture feeds. Moreover, building aquaculture ponds in mangrove areas transforms fisheries from a common property resource available to multiple users to a privatized farm resource.

Use of wild seed to stock aquaculture ponds. Many aquaculture operations, especially extensive ponds, stock wild-caught rather than hatchery-reared finfish or shellfish post-larvae. Examples include farming of milkfish in the Philippines and Indonesia, tuna in South Australia, shrimp in south Asia and parts of Latin America and eels in Europe and Japan. In these systems, aquaculture is not a true alternative to wild harvests, but rather a means to raise wild fish to marketable size in captivity by lowering the high mortality rates characteristic of wild populations.

If bycatch rates are high, collecting seedstock for aquaculture operations can have very large consequences for wild fisheries. For example, milkfish constitute only $15 \%$ of total finfish fry collected 
inshore by seine net ${ }^{38}$ - the remaining $85 \%$ are discarded and left to die on the beach. The 1.7 billion wild fry stocked annually in Philippine milkfish ponds ${ }^{39}$ thus result in a loss of about 10 billion fry of other finfish species. In India and Bangladesh, up to 160 fish and shrimp fry are discarded for every fry of the giant tiger shrimp, Penaeus monodon, collected to stock shrimp ponds ${ }^{40,41}$. The magnitude of annual fry bycatch is estimated at 62 million to 2.6 billion in three collecting centres in West Bengal, India ${ }^{40}$.

Food web interactions. Many small pelagic fisheries exploited for feed are over-fished and are strained by climatic variability associated with El Niño Southern Oscillation events ${ }^{8,10}$. The impact of pelagic fisheries depletion is thought to reduce available food supplies for marine predators, including valuable species consumed by humans ${ }^{42-44}$. In the North Sea, for example, over-exploitation of many capelin, sandeel and Norway pout stocks, mainly for reduction to fishmeal, has been implicated in the declines of certain stocks of other wild fish such as $\operatorname{cod}^{9,45,46}$, and changes in the distribution, populations sizes and reproductive success of various seal and seabird colonies ${ }^{47-49}$. Similarly, a strong interaction between anchoveta and sea bird and mammal populations has been well documented for the Peruvian upwelling system ${ }^{50}$.

Introduction of non-indigenous organisms. In some cases, aquaculture affects stocks of wild and farmed fish through biological pollution. Atlantic salmon-the dominant salmon species farmed-frequently escape from net pens. As much as $40 \%$ of Atlantic salmon caught by fishermen in areas of the North Atlantic Ocean are of farmed origin ${ }^{51}$. In the north Pacific Ocean, over 255,000 Atlantic salmon have reportedly escaped since the early 1980 s and are caught by fishing vessels from Washington to Alaska ${ }^{52}$. Increasing evidence suggests that farm escapees may hybridize with and alter the genetic makeup of wild populations of Atlantic salmon which are genetically adapted to their natal spawning grounds ${ }^{53}$. Such genetic alterations could exacerbate the decline in many locally endangered populations of wild Atlantic salmon ${ }^{53-55}$.

Movement of stocks for aquaculture purposes can also increase the risk of spreading pathogens. The relationships between farmed and wild fish and disease transfer are complex and often difficult to disentangle. In Europe, however, serious epidemics of furunculosis and Gyrodactylus salaris in stocks of Atlantic salmon have been linked to movements of fish for aquaculture and re-stocking ${ }^{56}$.

Since the early 1990s, Whitespot and Yellowhead viruses have caused catastrophic, multimillion-dollar crop losses in shrimp farms across Asia. Both pathogens have recently appeared in farmed and wild shrimp populations in the United States ${ }^{57,58}$ and the Whitespot virus has been reported in several countries in Central and South America (T. Flegel, personal communication; D. V. Lightner, personal communication). The Whitespot virus has

\section{Box 1}

\section{Loss of wild fish from habitat conversion}

For each hectare of mangrove, about $600 \mathrm{~kg}$ of finfish ${ }^{88}$ and $600 \mathrm{~kg}$ of shrimp ${ }^{34}$ are captured annually near shore in Malaysia. Applying this catch/mangrove area correlation to coastal regions of Thailand - where an estimated 65,000 ha of mangroves have been converted to shrimp ponds ${ }^{89}$ - indicates potentially significant losses in wild fish production. Shrimp ponds in Thailand have average annual yields of $3,000 \mathrm{~kg} \mathrm{ha}^{-1}$ (ref. 90); on balance, therefore, about $200 \mathrm{~g}$ each of fish and shrimp may be lost for every kilogram of shrimp farmed. Resident finfish species in mangrove waters comprise $97 \%$ of total fish biomass, which is equivalent to about $10.1 \mathrm{~g} \mathrm{~m}^{-2}$ of mangroves ${ }^{91}$. These numbers translate into an estimated loss of more than $100 \mathrm{~kg}$ of on-site fish biomass for every hectare of converted mangrove, or $34 \mathrm{~g}$ resident fish per kilogram farmed shrimp. Adding capture fisheries losses within mangrove areas to those nearshore results in a total reduction of fisheries biomass of $434 \mathrm{~g}$ per kilogram farmed shrimp due to habitat conversion alone. caused high mortalities in Texas shrimp farms ${ }^{59}$ and may cause mortality of wild crustaceans (Joint Subcommittee on Aquaculture Virus Working Group, personal communication). This virus is thought to have been introduced into a Texas shrimp farm by release into nearby coastal waters of untreated wastes from plants processing imported Asian tiger shrimp ${ }^{60}$, and by shipping of contaminated white shrimp Litopenaeus vannamei larvae throughout the Americas (T. Flegel. personal communication).

Effluent discharge. Untreated wastewater laden with uneaten feed and fish faeces may contribute to nutrient pollution near coastal ponds and cages ${ }^{61,62}$. Pollution problems are most severe in shallow or confined water bodies ${ }^{63}$; they also tend to be serious in regions where intensive aquaculture systems are concentrated. In many such areas, sedimentation of food particles and faecal pellets under and around fish pens and cages negatively affects the biogeochemistry of benthic communities ${ }^{64}$. Moreover, nitrogen wastes (for example, ammonia and nitrite) that exceed the assimilative capacity of receiving waters lead to deterioration in water quality that is toxic to fish and shrimp ${ }^{65}$. Problems of effluent discharge from aquaculture have been widely discussed, but management options for altering nitrogen biogeochemistry are based mostly on controlling the intensity of fish production in monoculture and polyculture systems $^{65}$. Aquaculturists have a stake in regulating nutrient pollution, because poor water quality and high stocking densities often promote outbreaks of pathogens and subsequent declines in farm productivity.

\section{Towards sustainable aquaculture}

The evidence presented above shows that total world aquaculture production currently adds to net global fish supplies, although many types of aquaculture result in a net loss of fish. Aquaculture's potential contribution to fish supplies is severely diminished by rapid growth in production of species fed carnivorous diets and by aquaculture practices that lead to coastal habitat destruction, biological pollution and discharge of untreated effluents. Continued expansion of aquaculture will require healthy coastal and freshwater ecosystems. Without clear recognition of the industry's dependence on natural ecosystems, it is unlikely that aquaculture will develop to its full potential or will continue to supplement ocean fisheries. We therefore suggest that the aquaculture industry prioritizes the following four chief goals: (1) expansion of the farming of low trophic level fish; (2) reduction of fish meal and fish oil inputs in feed; (3) development of integrated farming systems; and (4) promotion of environmentally sound aquaculture practices and resource management.

Farming down the food web. Carps and marine molluscs account for more than three-quarters of current global aquaculture output, and tilapia, milkfish and catfish contribute another $5 \%$ of total production. Fed mainly on herbivorous diets, these species provide most of the $19 \mathrm{Mt}$ gain in fish supplies from aquaculture shown in Fig. 1. But market forces and government policies in many countries favour rapid expansion of high-value, carnivorous species, such as salmon and shrimp. Moreover, fish meal and fish oil are already being added to carp and tilapia feeds for weight gain, especially in Asia where farming systems are intensifying as a result of increased scarcity and value of land and freshwater resources. Given the huge volume of farmed carp and tilapia in Asia, significant increases in the fish meal and fish oil content of feed could place even more pressure on pelagic fisheries, resulting in higher feed prices and harm to marine ecosystems.

New initiatives by governments and international donor agencies are needed to further encourage farming of low trophic level fish with herbivorous diets ${ }^{66-69}$. At the same time, more scientific research on the feed requirements of herbivores and omnivores is required to lessen the impetus to add fish meal and fish oil to their feeds ${ }^{69}$. Substituting vegetable oils for fish oils in freshwater fish diets is technically possible - the n-3 fatty acids in fish oil are not 


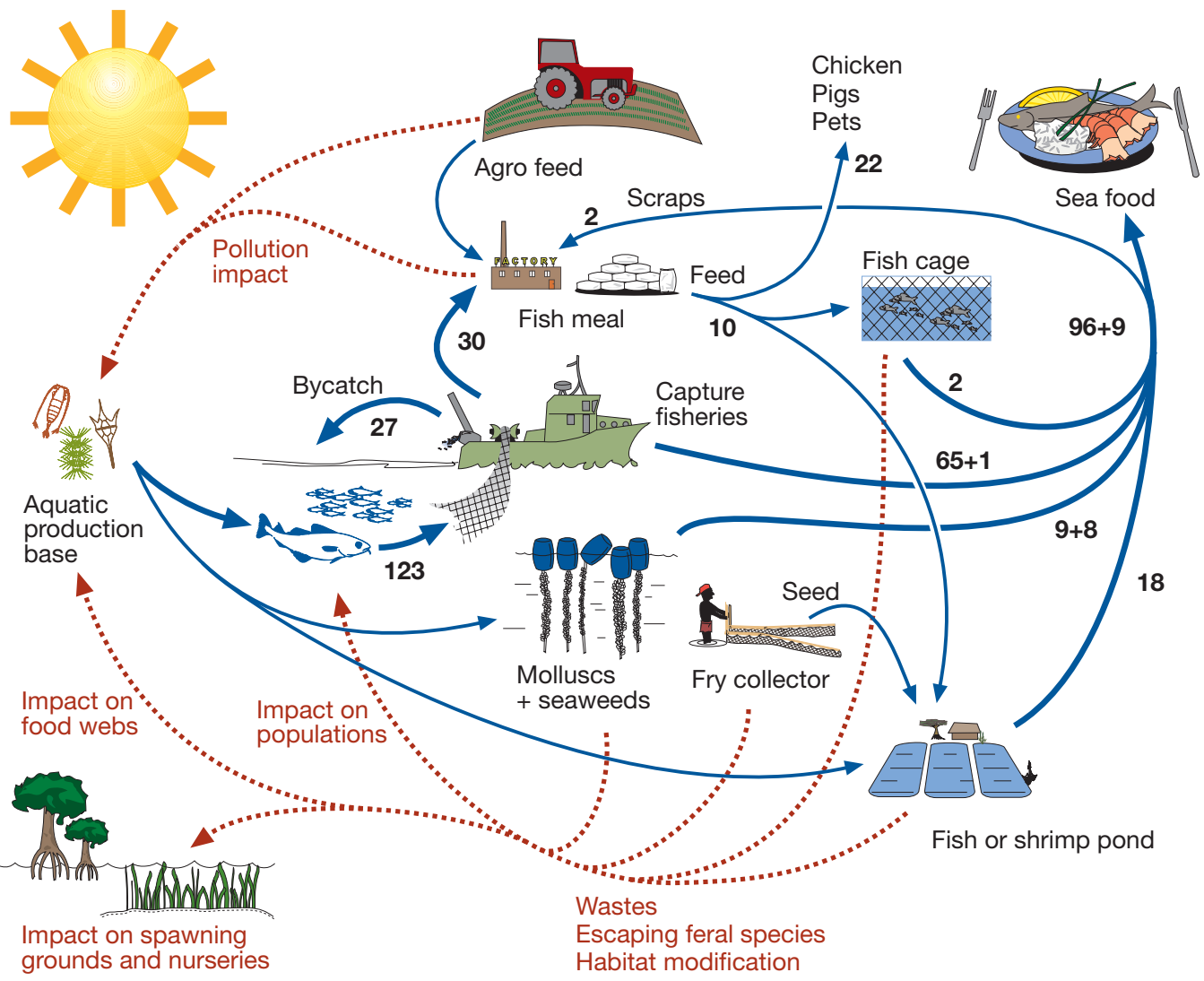

Figure 2 Ecological links between intensive fish and shrimp aquaculture and capture fisheries. Thick blue lines refer to main flows from aquatic production base through fisheries and aquaculture to human consumption of seafood. Numbers refer to 1997 data

and are in units of megatons (million metric tonnes) of fish, shellfish and seaweeds. Thin blue lines refer to other inputs needed for production. Hatched red lines indicate negative feedbacks.

essential in such diets ${ }^{70}$ — but the fatty acid profile and thus flavour and marketability may be affected ${ }^{71,72}$. Moreover, some herbivorous fish appear to have more robust immune systems when fish oil is included in their diet ${ }^{73}$.

Reducing fish meal and fish oil inputs in feed. Feed is the largest production cost for commercial aquaculture (for example, most farming of salmon, other marine finfish and shrimp), and thus improving feed efficiency in industrial systems is already a priority. Moreover, fish meal prices have risen in real terms in the past three decades and are likely to increase further with continued growth in demand. Increases in fish meal and fish oil prices could undermine the profitability of many aquaculture enterprises ${ }^{16}$.

Research to develop substitutes for these feed ingredients is now focused on commodities such as oilseeds (especially soybeans), meat byproducts (such as blood meal and bone meal) and microbial protein ${ }^{74,75}$. Already the fish meal content of some feeds has been reduced considerably, for example in the salmon industry, albeit largely by substitution with cheaper fish oil. Nevertheless, complete replacement of fish meal and fish oil in aquaculture feeds faces severe barriers. Especially for carnivorous fishes, vegetable proteins have inappropriate amino-acid balance and poor protein digestibility, although inclusion of meat byproducts can help overcome this problem $^{74,76}$.

Substitution of fish oil with cheaper vegetable oil in aquaculture feeds may also affect consumer demand, as evidence suggests that the ratio of n-6:n-3 fatty acids in human diets is already too high ${ }^{70,77}$. There are, however, alternative sources of n-3 fatty acids for humans, including molluscs and other types of seafood, and research is underway to increase the n-3 fatty-acid content in poultry products and in oilseeds used for feed ${ }^{78,79}$ (W. F. Kirk, personal communication). A move towards partial substitution of plant and terrestrial animal proteins for fish proteins in feed is widely accepted within the aquaculture industry, but the urgency of such efforts remains controversial. Because over-exploitation of pelagic fisheries has negative ecological and social consequences, developing a strategy to replace fish meal and fish oil in feeds should become both a private and public-sector priority.

Integrating production systems. Polyculture systems have been used for centuries. Even today, four of the most widely cultivated fish species are produced together in the same pond in China: silver carp (a phytoplankton filter feeder), grass carp (a herbivorous macrophyte feeder), common carp (an omnivorous detritus bottom feeder) and bighead carp (a zooplankton filter feeder) ${ }^{69,80}$. This type of system efficiently utilizes available food resources and water resources (that is, surface, pelagic and benthic) of the pond ecosystem, with the consequent effects of reducing costs and increasing productivity.

Integrated systems can also be used for high-valued fish, such as salmon and shrimp, to reduce effluents, diversify products and increase productivity. Several studies show that seaweed and mussels grow well in wastewater from intensive and semi-intensive systems, thereby reducing nutrient and particulate loads to the environment ${ }^{81-85}$. For example, in Chile salmon can be farmed with Gracilaria chilensis (an agarophytic red alga) that removes large amounts of dissolved nitrogen and phosphorous wastes from salmon cages ${ }^{86}$. The effluent output from salmon farming is used to produce a seaweed crop, and the added revenue from the sale of the seaweed more than pays for the extra infrastructure needed for the integrated system. Policies that require producers to internalize environmental costs of effluent discharge (for example, through mandatory sewage treatment) can make such systems even more profitable. The marketability of molluscs raised in intensive fish 
farming areas is currently constrained, however, by human health considerations that must be addressed to make these types of integrated system economically viable.

Promoting environmentally sound aquaculture and resource management. Long-term growth of the aquaculture industry requires both ecologically sound practices and sustainable resource management. Such practices can be encouraged by regulating the siting of ponds in mangroves and other coastal wetlands, establishing fines to minimize escapes from aquaculture netpens, enforcing strict biosafety measures for imported stock, and mandating treatment and recirculation of wastewater. Many aquaculturists have adopted such practices in the absence of strict policy measures, especially as environmental concerns have surfaced in recent years. In poor countries, however, these policies are often neither economically and socially feasible, nor politically enforceable. Despite significant improvements in the industry, there remains a considerable distance between ecologically sound technologies on the shelf and those actually implemented in the field. External funding agencies - such as development banks-are strategically positioned to influence the development of aquacultural technology, rehabilitation of ecosystems degraded by aquaculture and protection of coastal ecosystems.

How markets for resources are managed in the future will be a principal determinant of whether aquaculture depletes or enhances net fish supplies. The absence of regulations or price disincentives on coastal pollution, for example, limits mollusc farming and slows the adoption of non-polluting technologies by other marine aquaculture systems. Subsidies within the ocean fisheries sector often prevent farmed fish from substituting for wild fish catch, at least until fisheries are fully depleted.

Perhaps the largest unknown for both the private and public sectors is the future availability of freshwater for aquaculture production. Increasing scarcity of freshwater resources could severely limit the farming of herbivorous fish such as carps and tilapia. With a more binding constraint on freshwater systems, there is even more pressure to develop marine aquaculture systems that are ecologically and socially sound.

\section{Mandate for the future}

Fulfilling aquaculture's long-term potential to supplement global fish supplies and to provide food for the world's growing population will require a shared vision between the public and private sectors. Governments can support research and development on environmentally benign systems, eliminate implicit subsidies for ecologically unsound fish production, and establish and enforce regulatory measures to protect coastal ecosystems. At the same time, the private sector must alter its course and recognize that current practices that lead to dependence on pelagic fisheries, habitat destruction, water pollution and non-native introductions run counter to the industry's long-term health. If public and private interests act jointly to reduce external costs generated by farming systems, present trends may be reversed and the net contribution of aquaculture to global fish supplies can become increasingly positive. Without this shared vision, an expanded aquaculture industry poses a threat, not only to ocean fisheries, but also to itself.

1. Food and Agricultural Organization Aquaculture Production Statistics 1988-1997 (Food and Agricultural Organization, Rome, 1999).

2. Naylor, R. et al. Nature's subsidies to shrimp and salmon farming. Science 282, 883-884 (1998).

3. Williams, M. in Sustainable Aquaculture (ed. Bardach, J. E.) 15-51 (Wiley, 1997).

4. Muir, J. F. \& Young, J. A. Aquaculture and marine fisheries: will capture fisheries remain competitive? J. Northw. Atl. Fish. Sci. 23, 157-174 (1998).

5. Cremer, M., Baoxin, Z., Schmittou, H. \& Jian, Z. in International Aquafeed Directory and Buyers' Guide 1999 19-25 (Turret RAI, Middlesex, UK, 1999).

6. Milazzo, M. in World Bank Technical Paper no. 406 (The World Bank, Washington DC, 1998).

7. Johnson, H. M. Annual Report on the United States' Seafood Industry 6th edn (H. M. Johnson \& Associates, Bellevue, WA, 1998).

8. Food and Agricultural Organization The State of World Fisheries and Aquaculture 1998 (Food and Agricultural Organization, Rome, 1999).
9. Pauly, D., Christensen, V., Dalsgaard, J., Froese, R. \& Torres, F. Jr Fishing down marine webs. Science 279, 860-863 (1998).

10. National Research Council Sustaining Marine Fisheries (National Academy Press, Washington DC, 1999).

11. Tacon, A. G. J. Feeding tomorrow's fish. World Aquaculture 27, 20-32 (1996).

12. Crook, F. W., Hsu, H. \& Lopez, M. in Agricultural Outlook 13-16 (USDA Economic Research Service, Washington DC, 1999).

13. Robinson, E. Channel catfish. Int. Aquafeed 1, 15-23 (1998).

14. De Silva, S. S. \& Anderson, T. A. Fish Nutrition in Aquaculture (Chapman and Hall, London, 1994). 15. Pike, I. H. in International Aquafeed Directory (ed. Fraser, S.) 39-49 (Turret, Middlesex, UK, 1998) 16. Tacon, A. C. G. in International Aquafeed Directory (ed. Fraser, S.) 5-37 (Turret, Middlesex, UK, 1998).

17. Forster, J. Aquaculture chickens, salmon: a case study. World Aquaculture Magazine 30, 33,35-38, 40,69-70 (1999).

18. Odum, E. P. Fundamentals of Ecology (W. B. Saunders, Philadelphia, 1979).

19. Pauly, D. \& Christensen, V. Primary production required to sustain global fisheries. Nature 374, 255257 (1995).

20. Tacon, A. FAO aquaculture production update. Int. Aquafeeds 2, 13-16 (1998).

21. Alverson, D. L., Freeberg, M. H., Murawski, S. A. \& Pope, J. G. FAO Fisheries Technical Paper no. 339 (Food and Agricultural Organization, Rome, 1994).

22. Pike, I. H. Fishmeal outlook. Int. Aquafeeds 1, 5-8 (1998).

23. Tacon, A. Estimated global aquafeed production and aquaculture in 1997 and projected growth. Int. Aquafeed 2, 5 (1999).

24. Barlow, S. in Fish Farmer 40-43 (Amben, Surrey, UK, 1989).

25. Dalzell, P. \& Ganaden, R. A. A Review of the Fisheries for Small Pelagics in Philippine Waters. (Bureau of Fisheries and Aquatic Resources, International Center for Living Aquatic Resources Management, Quezon City, The Philippines, 1987).

26. Trinidad, A. C., Pomeroy, R. S., Corpuz, P. V. \& Aguero, M. Bioeconomics of the Philippine Small Pelagics Fishery (International Center for Living Aquatic Resources Management, Manila, The Philippines, 1993).

27. Robertson, A. I. \& Duke, N. C. Mangroves as nursery sites: comparisons of the abundance and species composition of fish and crustaceans in mangroves and other nearshore habitats in tropical Australia. Mar. Biol. 96, 193-205 (1987).

28. Primavera, J. H. Fish predation on mangrove-associated penaeids: The role of structures and substrate. J. Exp. Mar. Biol. Ecol. 215, 205-216 (1997).

29. Primavera, J. H. Mangroves as nurseries: shrimp populations in mangrove and non-mangrove habitats. Est. Coast. Shelf Sci. 46, 457-464 (1998).

30. Ronnback, P. The ecological basis for economic value of seafood production supported by mangrove ecosystems. Ecological Economics 29, 235-252 (1999).

31. Sasekumar, A., Chong, V. C. \& Lim, K. H. in Proceedings of the Third ASEAN-Australia Symposium on Living Coastal Resources: Status Reviews 1 (eds Wilkinson, C., Sudara, S. \& Ming, C. L.) 139-165 (Australian Institute of Marine Science, Townsville, Australia, 1994).

32. Martosubroto P. \& Naamin, M. Relationship between tidal forests (mangroves) and commercial shrimp production in Indonesia. Mar. Res. Indonesia 18, 81-86 (1977).

33. Camacho, A. S. \& Bagarinao, T. in Mangroves of Asia and the Pacific: Status and Management, Technical Report UNDP/UNESCO Research and Pilot Programme on Mangrove Ecosystem in Asia and the Pacific (RAS/79/002) (Natural Resources Management Center and National Mangrove Committee, Ministry of Natural Resources, Quezon City, The Philippines, 1987).

34. Sasekumar, A. \& Chong, V. C. in Proceedings of the 10th Annual Seminar of the Malaysian Society of Marine Sciences (Sasekumar, A., Phang, S. M. \& Chong, E. L.) 10-15 (Ardyas, Kuala Lumpur, Malaysia, 1987).

35. Ogden, J. C. The influence of adjacent systems on the structure and function of coral reefs. Proceedings of the International Coral Reef Symp. 1, 123-129 (1988).

36. Yanez-Arancibia, A., Lara-Dominguez, A. L. \& Day, J. W. Jr Interactions between mangroves and seagrass habitats mediated by estuarine nekton assemblages: coupling of primary and secondary production. Hydrobiologia 264, 1-12 (1993).

37. Munro, J. J. in Reef Fisheries (eds Polunin, C. R. \& Roberts, C. M.) 1-14 (Chapman and Hall, London, 1994).

38. Bagarinao, T. \& Taki, Y. in Indo-Pacific Fish Biology: Proceedings of the Second International Conference on Indo-Pacific Fishes (eds Uyeno, T., Arai, R., Taniuchi, T. \& Matsuura, K.) 728-739 (Ichthyological Society of Japan, Tokyo, 1986).

39. Bagarinao, T. in Tropical Mariculture (ed. de Silva, S.) 381-448 (Academic, London, 1998)

40. Banerjee, B. K. \& Singh, H. The Shrimp Bycatch in West Bengal (Bay of Bengal Programme, Madras, India, 1993).

41. Islam, M. M., Rahman, S. L., Halder, G. C., Mazid, M. A. \& Mahmood, N. Extent of damage to different crustaceans and fin fishes in collecting Penaeus monodon (Fabricius) post-larvae in Satkhira coastal region. J. Mar. Biol. Assoc. India 38, 1-7 (1996).

42. Folke, C. \& Kautsky, N. The role of ecosystems for a sustainable development of aquaculture. Ambio 18, 234-243 (1989).

43. Hamer, K. C., Monaghan, P., Uttley, J. D., Walton, P. \& Burns, M. D. The influence of food supply on the breeding ecology of kittiwakes (Rissa tridactyla) in Shetland. Ibis 135, 255-263 (1993).

44. Fischer, J., Haedrich, R. L. \& Sinclair, P. R. Interecosystem Impacts of Forage Fish Fisheries (EcoResearch Program, Memorial University of Newfoundland, Newfoundland, 1997).

45. Hislop, J. R. G. Changes in North Sea gadoid stocks. ICES J. Marine Science 53, 1146-1156 (1996).

46. Monaghan, P. Seabirds and sandeels - the conflict between exploitation and conservation in the northern North Sea. Biodivers. Conserv. 1, 98-111 (1992).

47. Wright, P. J. \& Begg, G. S. A spatial comparison of common guillemots and sandeels in Scottish waters. ICES J. Mar. Sci. 54, 578-592 (1997).

48. Brown, E. G. \& Pierce, G. J. Monthly variation in the diet of harbour seals in inshore waters along the southeast Shetland (UK) coastline. Mar. Ecol. Prog. Ser. 167, 275-289 (1998).

49. Phillips, R. A., Caldow, R. W. G. \& Furness, R. W. The influence of food availability on the breeding effort and reproductive success of Arctic skuas (Stercorarius parasiticus). Ibis 138, 410-419 (1996).

50. Pauly, D. in The Peruvian Anchoveta and its Upwelling Ecosystem: Three Decades of Change (eds Pauly, D. \& Tsukayama, I.) 325-342 (ICLARM, Manila, The Philippines, 1987).

51. Hansen, P., Jacobsen, J. A. \& Und, R. A. High numbers of farmed Atlantic salmon, Salmo salar 
observed in oceanic waters north of the Faroe Islands. Aquaculture Fisheries Management 24, 777-781 (1993)

52. McKinnell, S. \& Thomson, A. J. Recent events concerning Atlantic salmon escapees in the Pacific. ICES J. Mar. Sci. 54, 1221-1225 (1997).

53. Gross, M. R. One species with two biologies: Atlantic salmon (Salmo salar) in the wild and in aquaculture. Can. J. Fish. Aquat. Sci. 55 (Suppl.1), 1-14 (1998).

54. McGinnity, P. et al. Genetic impact of escaped farmed Atlantic salmon (Salmo salar L.) on native populations: use of DNA profiling to assess freshwater performance of wild, farmed, and hybrid progeny in a natural river environment. ICES J. Mar. Sci. 54, 998-1008 (1997).

55. Slaney, T. L., Hyatt, K. D., Northcote, T. G. \& Fielden, R. J. Status of anadromous salmon and trout in British Columbia and Yukon Fisheries. Am. Fish. Soc. 21, 20-35 (1996).

56. McVicar, A. H. Disease and parasite implications of the coexistence of wild and cultured salmon populations. ICES J. Mar. Sci. 54, 1093-1103 (1997).

57. Nadala, E. C. B. \& Loh, P. C. A comparative study of three different isolates of white spot virus. Dis. Aquat. Organisms 33, 231-234 (1998).

58. Lightner, D. V. A Handbook of Shrimp Pathological and Diagnostic Procedures for Diseases of Cultured Penaeid Shrimp (World Aquaculture Society, Baton Rouge, Louisiana, 1996).

59. Nunan, L. M., Poulos, B. T. \& Lightner, D. V. The determination of White Spot Shrimp Virus (WSSV) and Yellow Head Virus (YHV) in imported commodity shrimp. Aquaculture 160, 19-30 (1998).

60. Lightner, D. V. et al. Risk of spread of penaeid shrimp viruses in the Americas by the international movement of live and frozen shrimp. Rev. Sci. Tech. Off. Int. Epiz. 16, 146-160 (1997).

61. Braaten, B., Aure, J., Ervik, A. \& Boge, E. Pollution problems in Norwegian fish farming. ICES Coastal Management 26, 11 (1983).

62. Gowen, R. J. \& Bradbury, N. B. The ecological impact of salmonid farming in coastal waters: a review. Oceanogr. Mar. Biol. Ann. Rev. 25, 563-575 (1987).

63. Iwama, G. K. Interactions between aquaculture and the environment. Crit. Rev. Environ. Contr. 21, 177-216 (1991).

64. Ervik, A. et al. Regulating the local environmental impact of intensive marine fish farming. Aquaculture 158, 85-94 (1997).

65. Hargreaves, J. A. Nitrogen biogeochemistry of aquaculture ponds. Aquaculture 166, 181-212 (1998). 66. Tacon, A. J. Contribution to food fish supplies. FAO Fisheries Circular 886 (Rev. 1), 17-21 (1997).

67. Baily, C. Aquaculture and basic human needs. World Aquaculture 27, 28-31 (1997).

68. El-Sayed, A. M. Alternative dietary protein sources for farmed Tilapia, Oreochromis spp. Aquaculture 179, 149-168 (1999).

69. Tacon, A. J. \& De Silva, S. S. Feed preparation and feed management strategies within semi-intensive fish farming systems in the tropics. Aquaculture 151, 379-404 (1997).

70. Bell, J. G. in Biology of Farmed Fish (eds Black, K. D. \& Pickering, A. D.) 114-145 (Sheffield Academi Press, Sheffield, UK, 1998).

71. Morris, C. A., Haynes, K. C., Keeton, J. T., and Gatlin, D. M. Fish oil and dietary pelagics and flavor of channel catfish. J. Food Sci. 60, 1225-1227 (1995).

72. Steffens, W. Effects of variation in essential fatty acids in fish feeds on nutritive value of freshwater fish for humans. Aquaculture 151, 97-119 (1997)

73. Pilarczyk, A. Changes in specific carp immune reaction caused by addition of fish oil to pellets. Aquaculture 129, 425-429 (1995).

74. Webster, C. D., Tiu, L. G., Margan, A. M. \& Gannam, A. Effect of partial and total replacement of fishmeal on growth and body composition of sunshine bass, Morone chrysops X M. saxatilis, fed practical diets. J. World Aquaculture Soc. 30, 443-453 (1999).
75. Tacon, A. G. J. Feed Ingredients for Carnivorous Fish Species: Alternatives to Fishmeal and Other Fishery Resources (Food and Agricultural Organization, Rome, 1994).

76. Lim, C. \& Dominy, W. G. in Proceedings of the Aquaculture Feed Processing and Nutrition Workshop (eds Akiyama, D. M. \& Tan, R. K. H.) 163-172 (American Soybean Association, Singapore, 1991).

77. Pond, C. The Fats of Life (Cambridge Univ. Press, Cambridge, UK, 1998)

78. Huttenbauer, S. Entrepreneurship in Food Preservation and Nutriceuticals Harvard Business School Case Study (Harvard Business School Publishing, Boston, Massachusetts, 1999).

79. Mooney, J. W. Lipid and flavour quality of stored breast meat from broilers fed marine algae. J. Sci. Food Agriculture 78, 134-140 (1998).

80. Bardach, J. E., Ryther, J. H. \& McLarney, W. O. Aquaculture: the Farming and Husbandry of Freshwater and Marine Organisms (John Wiley, New York, 1972).

81. Jones, T. O. \& Iwama, G. K. Polyculture of the Pacific oyster, Crassostrea gigas (Thunberg), with chinook salmon, Oncorhynchus tshawytscha. Aquaculture 92, 313-322 (1991).

82. Neori, A. et al. Seaweed biofilters as regulators of water quality in integrated fish-seaweed culture units. Aquaculture 141, 183-199 (1996).

83. Phang, S. -M., Shaharuddin, S., Noraishah, H. \& Sasekumar, A. Studies on Gracilaria changii (Cracilariales, Rhodophyta) from Malaysian mangroves. Hydrobiologia 326/327, 347-352 (1996).

84. Troell, M., Ronnback, P., Kautsky, N., Halling, C. \& Buschmann, A. Ecological engineering in aquaculture: the use of seaweeds for removing nutrients from intensive mariculture. J. Appl. Phycology 11, 89-97 (1999).

85. Soto, D. \& Mena, G. Filter feeding by the freshwater mussel, Diplodon chilensis, as a biocontrol of salmon farming eutrophication. Aquaculture 171, 65-81 (1999).

86. Troell, M. et al. Integrated marine cultivation of Gracilaria chilensis (Gracilariales, Rhodophyta) and salmon cages for reduced environmental impact and increased economic output. Aquaculture 156, 45-61 (1997).

87. Food and Agricultural Organization Aquaculture production statistics 1987-1996. Fish. Circ. 815 (Rev. 10) (1998).

88. Singh, H. R., Chong, V. C., Sasekumar, A. \& Lim, K. H. in Proceedings of the Third ASEAN-Australia Symposium on Living Coastal Resources: Status Reviews (eds Wilkinson, C., Sudara S. \& Ming, C. L.) 105-122 (Australian Institute of Marine Science, Townsville, Australia, 1994).

89. Menasveta, P. Mangrove destruction and shrimp culture systems. World Aquaculture 28, 36-42 (1997).

90. Rosenberry, B. (ed.) World Shrimp Farming (Shrimp News International, San Diego, California, 1998)

91. Ronnback, P., Troell, M., Primavera, J. H. \& Kautsky, N. Distribution pattern of shrimps and fish among Avicennia and Rhizophora microhabitats in the Pagbilao mangroves, Philippines. Est. Coast. Shelf. Sci. 48, 223-234 (1999).

\section{Acknowledgements}

We thank M. Williams, W. Falcon, V. Spruill, M. Drew, N. Wada, R. Kautsky, K. Jauncey, C. Tirado, R. Hoguet, R. Tatum and R. Mitchell for comments and assistance, and the David and Lucile Packard Foundation for funding.

Correspondence and requests for materials should be addressed to R.L.N (e-mail: roz@leland.stanford.edu). 